\title{
Defective Thyroglobulin Transport
}

National Cancer Institute

\section{Source}

National Cancer Institute. Defective Thyroglobulin Transport. NCI Thesaurus. Code C131432.

Impairment in the intracellular transport of thyrog lobulin. 